\title{
Physiological Changes in the Germination Seeds during the Low Temperature Treatment I
}

\author{
On the Water Content, the Specific Gravity of the Tissue Powder \\ and the Concentration of Reducing Sugars of Horse Bean
}

\section{by Masaki YAHIRo* and Takashi INOUE}

\begin{abstract}
八尋正樹・井上 喬： 低溫处理の発芽種子の生理的変化 I. 水分含量粉末比重及び還元糖について Received December, 4, 1954
\end{abstract}

\section{Introduction}

In some plants the flower initiation is accelerated by subjecting the seeds to a low temperature treatment during the first stages of germination. Many investigations wers hitherto made as to the mechanism of the vernalization with few satisfactory results.

The authors carried out several experiments with horse beans to see the inner physiological changes taking place during and after the vernalization procedure. As the water content of the cell as well as of the tissue had been considered to have usually a close relationship with the reactions occurring in the plant, the variation in the amount of water during the course of vernalization was first investigated. The specific gravity of the tissue powder was also measured, because this had been introduced by Koketsu1,2) and regarded as a suitable index giving a reasonable standard at the quantitative investigation. Finally the authors studied on the changes in the amount of reducing sugars by low temperature treatment.

This investigation was carried out in the Botanical Laboratory Faculty of Agriculture, Kyushu University.

The authors are grateful for the kind suggestion and encouragement given them by Proffessor Hitoshi Kojima; and they are also indebted to Ass. Proffesor Yoshio Tashima of Kagoshima University for his valuable suggestions during the course of the experiment.

\section{Material and Methods}

As the material some of the usual garden varieties of horse bean were used, because they germinate at any time from the early spring to the beginning of summer. The material was divided into two groups by the colours of the seed ceat:

* Faculty of Agriculture, Kagoshima University 鹿見島大学農学部 
namely green (that means the imperfect ripeness) and light brown (the perfect ripeness).

The seeds were immersed in water for 24 hours so that they absorb enough water; after the disinfection by a $0.01 \%$ solution of corrossive sublimate, they were washed throughly with water and put on a disinfected, suitably wet gauze in a china container and placed in an incubator of $25^{\circ} \mathrm{C}$. After about 40 hours the seeds sprouted to a length of $4 \mathrm{~mm}$. to $5 \mathrm{~mm}$. The material, selected from these seeds, were subjected to a temperature of $0^{\circ} \mathrm{C}$ or $7^{\circ} \mathrm{C}$ with the control, the durations of the treatment being 7-, 9-, 14-, and 21-days. When the treatment was finished, a part of the material was used for measuring the physiological features cited below, and another part of the material was planted on pots, which were placed in a greenhouse in order to protect them from the coldness of early spring.

To calculate the water content of the seed, the authors removed the seed coat and weighed the naked embryo only, because the water, absorbed in the seed coat as well as contained between the coat and the embryo, was thought to have not only no physiological significance in the persent study, but also there was some possibility to make the confused or disturb the estimation.

The specific gravity of the tissue powder was determined by weighing a unit powder-capacity of the material-or an unit volume of powder specially measured after Koketsu's powder method.

Reducing sugars were measured by Bertrand's method, and the sugar content was denoted by its amount contained in an unit powder-capacity of the material.

In order to test whether the vernalization was successful or not, fifteen plants of each lot of material were potted, as mentioned above, and the flower initiation was examined on April 25 and May 12. Number of leaves up to the node which bears the first flower bud, was also counted-the smaller thus number, the more advanced is the vernalization.

\section{Experimental results and Discussion}

\section{1) Water content}

The water content generally increased with the progress of the low temperature treatment as shown in Fig. 1. It is clear that the water is indispensable for various reactions which take place in the plant body and the increase in the water content generally indicates the increment in physiological activity of the plant.

The water content in both the perfectly ripe and the imperfectly ripe seeds after the treatment at $7^{\circ} \mathrm{C}$ was higher than that caused by the treatment at $0^{\circ} \mathrm{C}$. From this fact and also from the value of specific gravity of the tissue powder (mentioned below), the lower temperature, $0^{\circ} \mathrm{C}$, was seemingly too cold and caused the unfavorable changes in the plant tissues. 


\section{2) Specific gravity of the tissue powder}

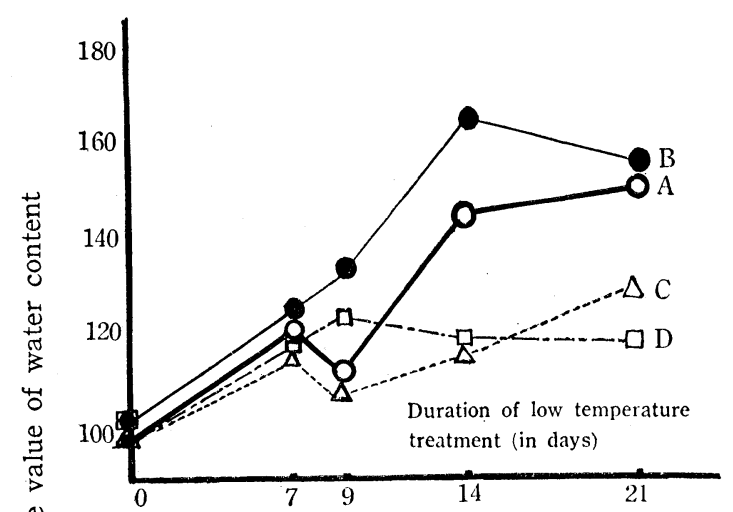

A: Green, imperfectly ripe seed and

B: light brown, perfectly ripe seed, held at $7^{\circ} \mathrm{C}$.

C: Green, imperfectly ripe seed and

$\mathrm{D}$ : light brown, perfectly ripe seed, held at $0^{\circ} \mathrm{C}$.

Fig. 1. Change in the water content
The specific gravity of the tissue powder treated at $7^{\circ} \mathrm{C}$ was always greater than that treated $0^{\circ} \mathrm{C}$, where the activity of the dissimilating reaction and the transformation and transportation of the substances were retarded by the low temperature.

Taguchi3,4) reported that the specific gravity of the tissue powder of the mulberry tree increased in winter. It might be reasonable to say that this result shows the same tendency in mulberry tree as in horse bean as regards the effect of the low temperature. The specific gravity of the tissue powder

seems to have some relation with the vernalization, although it may be indirect collateral.

\section{3) The amount of reducing sugars}

As shown in table 3, there were found two peaks in the amount of reducing

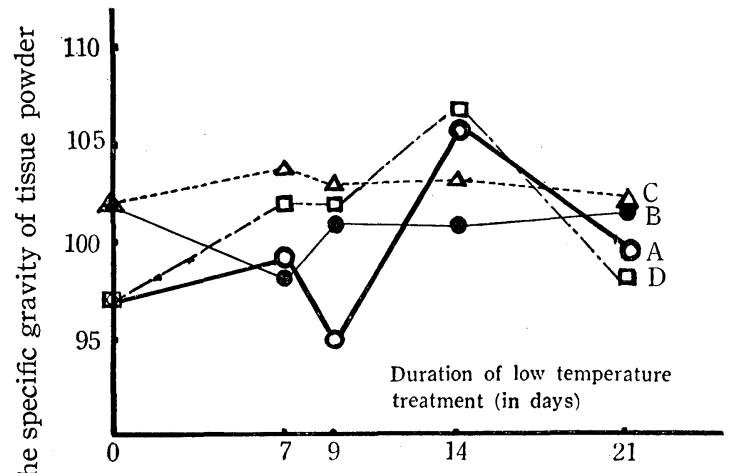

A: Green, imperfectly ripe seed and $\mathrm{B}$ : light brown, perfectly ripe seed, held at $7^{\prime} \mathrm{C}$.

C: Green imperfectly ripe seed and D: light brown perfectly ripe seed, held at $7^{\circ} \mathrm{C}$.

Fig. 2. Change in the specific gravity of the tissue powder sugars of the material treated at low temperature, as to the length of the duration of the treatment. The material of 7-day treatment showed somewhat higher value and that of 14-day treatment highest. Generally speaking, this phenomenon can be seen in a similar was in the material treated at $0^{\circ} \mathrm{C}$ as well as in that treated at $7^{\circ} \mathrm{C}$, almost regardless of the ripeness of the seed, perfect or imperfect. It is most likely that the increase in the reducing sugars to the higher activity of the hydrolyzing enzymes.

An unexpected extraordinaly shortness in the value of the reducing sugars content (and indeed this was the result of two parallel experiments) in the imperfectly ripe seed treated at $0^{\circ} \mathrm{C}$ for 14 days, could not be explained exactly. 
The works in the winter wheat by Oveckin and others (1936) indicated that there was no relation between the amount of sugars and the vernalization; on the other hand Gregory and Purvis (1936), Gregory and De Ropp (1938), and Yamasaki (1943, 1944) put stress on the importance of sugars. The first of these authors stated that the growing embryo of the grain is able to synthesize hormones from the substratum containing glucose and inorganic salts. Gregory and De Ropp showed

A : Green, imperfectly ripe seed and B: light brown, perfectly ripe seed, held at $7^{\circ} \mathrm{C}$.

$\mathrm{C}$ : Green, imperfectly ripe seed and $\mathrm{D}$ : light brown, perfectly ripe seed, held at $0^{\circ} \mathrm{C}$.

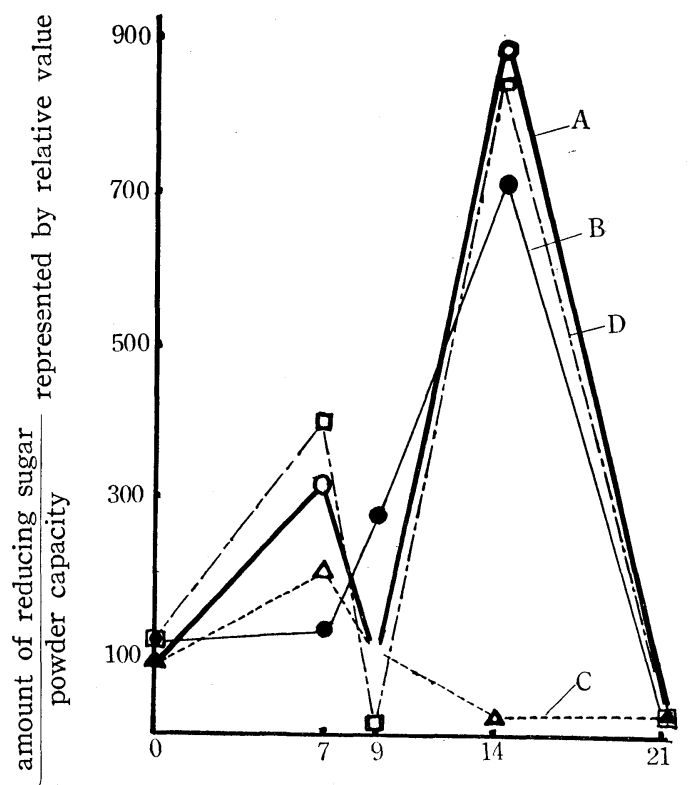

Fig. 3. Change in amount of reducing sugars

further that if sugar is excluded from the medium in which the excised embryos were to be grown, they remained unvernalized. Recently Tashima ${ }^{10)}$, Imamura and Tashima11) pointed out the importance of sugars to vernalize the embryo of radish plant in total darkness. On the other hand Kojima, Yahiro and Inoue ${ }^{12)}$ concluded that the supply of sugars is not strictly necessary for the vernalization of cotyledonless radish seedlings, althoug the supplying is somewhat favorable to vernalize them.

To the authors' regret, owing to the lake of untreated material (control), the material treated at low temperatures could not be compared with the control, in regard to the sugar content in the lapse of treatment.

\section{4) Investigations on the first flower bud and flowering}

The effect of vernalization increases with the progress of the low temperature treatment, as seen in Tables 3 and 4 ; and the temperature of $0^{\circ} \mathrm{C}$ is more effective than $0^{\circ} \mathrm{C}$. Perfectly ripe and imperfectly ripe seeds which were treated at $7^{\circ} \mathrm{C}$ for 21 days showed 100\% flowering within 47 days after planting, and on the other hand those which were not treated at a low temperature indicated only $20 \%$ flowering in the case of the imperfectly ripe seed, and $0 \%$ in the perfectly ripe seeds within 68 days after the planting, respectively.

The authors also ascertained in the field experiment that the number of leaves up to the first flower bud decreased with the progress of the low temperature treatment a sign of effective vernalization.

It is noticeable that the fall of flower buds prior to the flowering was often 
observed on the plants grown up from the seedlings treated at low temperature during insufficient time length.

Table I. Condition of flowering on pots *

\begin{tabular}{|c|c|c|c|c|c|c|c|c|c|c|c|c|c|c|c|c|}
\hline \multirow{3}{*}{$\begin{array}{c}\begin{array}{c}\text { Duration } \\
\text { of low } \\
\text { temperature } \\
\text { treatment } \\
\text { (in days) }\end{array} \\
0\end{array}$} & \multirow{2}{*}{\multicolumn{2}{|c|}{$\begin{array}{l}\begin{array}{c}\text { Days after } \\
\text { the } \\
\text { treatment }\end{array} \\
\text { April } 25 \\
\text { May } 12\end{array}$}} & \multirow{2}{*}{\multicolumn{2}{|c|}{$\begin{array}{c}\begin{array}{c}\text { Days after } \\
\text { the } \\
\text { planting }\end{array} \\
\text { April } 25 \\
\text { May } 12\end{array}$}} & \multirow{2}{*}{\multicolumn{3}{|c|}{$\begin{array}{l}\text { A: Green, } \\
\text { imperfectly } \\
\text { ripe seed } \\
\text { held at } 7^{\circ} \mathrm{C} \\
{ }^{* *} \\
\text { a b c }\end{array}$}} & \multicolumn{3}{|c|}{$\begin{array}{c}\text { B: Light } \\
\text { brown, per- } \\
\text { fectly ripe seed } \\
\text { held at } 7^{\circ} \mathrm{C}\end{array}$} & \multicolumn{3}{|c|}{$\begin{array}{l}\text { C: Green, } \\
\text { imperfectly } \\
\text { ripe seed } \\
\text { held at } 0^{\circ} \mathrm{C}\end{array}$} & \multicolumn{3}{|c|}{$\begin{array}{c}\text { D: Light } \\
\text { brown, per- } \\
\text { fectly ripe seed } \\
\text { held at } 0^{\circ} \mathrm{C}\end{array}$} \\
\hline & & & & & & & & a & b & c & a & b & c & $\mathrm{a}$ & $\mathrm{b}$ & c \\
\hline & 52 & 68 & 52 & 68 & 40 & 20 & $10-11$ & 40 & 20 & $10-11$ & 0 & 0 & - & 0 & 0 & - \\
\hline 7 & & 68 & 45 & 61 & 73 & 73 & $9-10$ & 40 & 27 & $10-11$ & - & - & - & 0 & 30 & 11 \\
\hline 9 & 52 & 68 & 43 & 59 & 80 & 73 & $9-10$ & 47 & 53 & $10-11$ & 57 & 57 & $9-10$ & 200 & 40 & $10-11$ \\
\hline 14 & 52 & 68 & 38 & 54 & 87 & 80 & 8-9 & 61 & 67 & $9-10$ & 57 & 57 & 8-9 & 20 & 50 & 10 \\
\hline 21 & 52 & 68 & 31 & 47 & 87 & 100 & $7-8$ & 61 & 67 & $9-10$ & 100 & 100 & 8 & - & - & - \\
\hline
\end{tabular}

*) Planted on March 3, 1950. The number of individuals planted: 15

**) Number of plants bearing flower buds (indicated by percent), a: Total number of plants, taken April 25. b: The same as the above, taken May 12. c: Number of leaves up to the node of the first flower bud.

\section{Summary}

1. With a variety of horse beans, the variation in the water content, the specific gravity of the tissue powder and the amount of reducing sugars caused by the low temperature treatment at $7^{\circ} \mathrm{C}$ and $0^{\circ} \mathrm{C}$ were studied.

2. The water content of the material treated at $7^{\circ} \mathrm{C}$ was much greater than that treated at $0^{\circ} \mathrm{C}$.

3. On the contrary, the specific gravity of the tissue powder was smaller in the former case in the latter.

4. The amount of reducing sugars both in the material treated at $7^{\circ} \mathrm{C}$ and at $0^{\circ} \mathrm{C}$ showed the similar change and it increased with the progress of the treatment up to 14 days.

5. It was found that the treatment at $7^{\circ} \mathrm{C}$ was more effective than that at $0^{\circ} \mathrm{C}$ as regards to the vernalizing effect in the field experiment.

6. The effect of vernalization increased with the progress of the low temperature treatment and the period of 21 days was the most effective for vernalization in the present experiments.

7. The fall of flower buds prior to the sufficient flowering was sometimes observed on the plants grown from the seedlings which were treated at low temperature during insufficient time length. 


\section{References}

1. Koketsu, R. Jour. Dept. Agr. Kyushu. Imp. Univ. 1: 151 (1924)

2. Koketsu, R. Bot. Mag. Tokyo. 93: 169 (1925)

3. Taguchi, R. Jour. Ser. Sci. Jap., 9: 42 (1938)

4. Taguchi, R. Res. Rep. Fac. Tex. Ser. Shinshu. Univ. Jap. 11 (1952)

5. Oveckin, S. K. \& others. Agrofizol. 1: 35 (1948) (cited from vernalization and photoperiodism Symposium by Murneek, A. E. \& Whyte, R. O.)

6. Gregory, F. G. \& Purvis, O. N. Ann. Bot. N. S. 2: 237 (1938)

7. Gregory, F. G. \& De Ropp, R. S. Nature 142: 481 (1938)

8. Yamasaki, Y. Kagaku (Japan), 13, 159. (1943)

9. Yamasaki, Y. Agricult. \& Horticult. (Japan) 19: 989 (1944)

10. Tashima, Y. Proc. Japan. Acad. 29: 271 (1953)

11. Imamura, S. \& Tashima, Y. Proc. Japan. Acad., 29: 581 (1953)

12. Kojima, H., Yahiro, M. \& Inoue, T. Bot. Mag. Tokyo. 67 : 112 (1954)

抄錄

N-carbamoyl 誘導体にしたアミノ酸のクロマトグラフィー

[Phillips D. M. P.: Chromatography of the N-Carbamoyl-amino acids Biochim. Biophys. acta 13: 56 (1954)]

近年パーパークロマトグラフィーは広く利用さ れているが，アミノ酸の面に倣いても検出同定を 容易にする為色々な展開凪, 展開法が発表せられ て来た。著者はアミノ酸を Carbamoyl 誘導体に する事により高いRf 值を得, 多種のアミノ酸の 分離を容易にした。一方発色剂についてはNinhydrine の利用と共に N-Carbomoyl アミノ酸, Citrulline，尿素等には $4 \%$ p-Dimethylamino benzaldehyde による黄色反応を, Cysteine, Cystine には $2 \%$ Nitroprusside, $20 \% \mathrm{NaCO}_{3}, 2 \mathrm{M}$
$\mathrm{NaCN}$ 混液による赤色反応を又 Arginine には アルカリ性 $\alpha$-Naphthol 液と KBrO 液との混液 による桃色反応を侀用し検出を一層簡便にした。 N-Carbamoyl 誘導体はアミノ酸溶液を多量の $\mathrm{KCN}$ と共に試験管中で.1〜2時間 $100^{\circ} \mathrm{C}$ で熱す る事により合成する, 又此のものは展開後 Pyridine で溶出され比色定量する事も出来た。な打 展開は二次元法を用いたが最良の結果を得た展開 威はブタノール, 水, 酢酸 $(5: 1: 4)$ と水飽和 Phenol の場合であつた。（山本茂） 